\title{
Cutaneous immune system: Age specificities
}

\section{Markelova Elena Vladimirovna ${ }^{1}$, Yana Alexandrovna Yutskovskaya ${ }^{1}$, Birko Oksana Nikolaevna ${ }^{2}$, Bajbarina Elena Valerjevna $^{2}$, Natalya Sergeevna Chepurnova ${ }^{{ }^{*}}$}

${ }^{1}$ FSBEI HE Pacific State Medical University of the Ministry of Health of the Russian Federation, Vladivostok

${ }^{2}$ Professor Yutskovskaya's Clinic, Ltd, Moscow

\begin{abstract}
The review is dedicated to the modern concepts in understanding the age-related changes of skin protective functions, with an emphasis on the impairments in interaction between the immune cells of innate and acquired immunity, resulting in a decrease in antigen-specific $\mathrm{T}$ cell immune surveillance in the skin. We discuss the various defects of $\mathrm{T}$ cells and their environment as well as focus on the issue of possible correction of T-reg and other cells activity in the skin which would increase the level of immune surveillance in elderly persons and reduce the risk of malignant neoplasms or skin infections developing.
\end{abstract}

Keywords: skin; innate and adaptive immunity; aging

Citation: Vladimirovna ME, Yutskovskaya YA, Nikolaevna BO, Valerjevna BE, Chepurnova NS, Cutaneous immune system: Age specificities. J Surg Dermatol 2022; 7(1): 161; http://dx.doi.org/10.18282/jsd.v7.i1.161.

*Correspondence to: Chepurnova Natalya Sergeevna, Normal and Pathological Physiology Department, FSBEI HE Pacific State Medical University of the Ministry of Health of the Russian Federation, 2 Ave Ostryakova, Vladivostok; dr.cns@ yandex.ru

Received: $4^{\text {th }}$ August 2021; Accepted: $30^{\text {th }}$ September 2021; Published Online: $27^{\text {th }}$ October 2021

\section{Introduction}

Substantial sensitivity increases to infections and malignant neoplasms observed in elderly persons designates skin protective properties decline during aging. This review focuses on the modern concepts in understanding the agerelated changes of skin protective functions focusing on how the impairments in interaction between the immune cells of innate and acquired immunity result in a decrease in antigen-specific T-cell immune surveillance in the skin. A criterion for the inclusion of literature sources in this review was research in the field of skin immunology in a young and aging people, exclusion criteria were studies in the field of immunology and the pathogenesis of skin diseases.

\section{Skin and immunity}

Cutaneous integument forms the body interface with the environment and performs the main barrier function. Skin defends the body, making it impervious from a multitude of harmful exogenic substances, maintains homeostasis and prevents from moisture and heat loss. In addition, it is a highly specialized immune system, composed of resident, activated or migrated to a tissue leucocytes (Table 1). These cells are distributed in the epidermal and dermal skin layers and participate in the mechanisms of innate and acquired immunity. They are responsible for a "self" and "non-self", being fundamentally important, as skin every day contacts with exogenic substances. Close interrelation between these two ways of innate and acquired immunity realization plays an important role in activation and strengthening of cutaneous integument immune response.

Skin immune function decreases in elderly persons, resulting in the growth of bacterial (Streptococcal and Staphylococcal cellulitis) and fungal (mostly Candida) infection ${ }^{[3]}$, contributing to an increase in cases of malignant neoplasms of the $\operatorname{skin}^{[4]}$. One of the key mechanism of skin aging is a reduction in a cell self-renewal. Progressive decrease of a cell proliferative activity causes the elevation in the old cells count and driving of adaptation, hypotrophy, and other processes ${ }^{[5]}$. Aging skin is noted to involve mononuclear infiltration, Langerhans cells count decreasing as well as changes in production of immunocompetent cytokine cells responsible for proliferation and differentiation of skin cells ${ }^{[6]}$. Cutaneous immune system, morphologically presented with skin-associated lymphoid tissues (SALT), from the one side, is a rather autonomic structure of the bodily immune system, from the other side, it is closely morphologically and regulatory interconnected with the bodily immune system. Disturbances of normal cutaneous immune reactions result in an onset of diverse

Copyright (C) 2022 Vladimirovna ME, et al. This is an Open Access article distributed under the terms of the Creative Commons AttributionNonCommercial 4.0 International License (http://creativecommons.org/licenses/by-nc/4.0/), permitting all non-commercial use, distribution, and reproduction in any medium, provided the original work is properly cited. 
Table 1. Cells of innate and acquired skin immunity ${ }^{[1,2]}$

\begin{tabular}{llll}
\hline & Resident & Activated & Migrated \\
\hline Innate immunity & Keratinocytes & Monocytes & NK-cells \\
& Endothelial cells & Granulocytes & Dendritic cells \\
& - vascular & - basophils & \\
& - lymphatic & - eosinophils & \\
& Dendritic cells & - neutrophils & \\
& Mast cells & Mast cells & ? Promonocyte \\
& Tissue macrophages & Epithelioid cells & \\
Acquired immunity & T-lymphocytes & T-lymphocytes & T-lymphocytes \\
\hline
\end{tabular}

? - Reflects the probability in this case

dermatological diseases and in the most of aesthetic problems, a premature skin aging being among them. With aging cells start to secrete a complex of cytokines and growth factors, modifying tissue microenvironment. This phenomenon is named senescence-associated secretory phenotype (SASP) ${ }^{[7,8]}$. Gomez (2007) correlates advanced age with the hyperproduction of proinflammatory cytokines (determining this process as "Inflamm-aging"), such as IL-1 $\beta$, IL-6 and TNF $\alpha^{[9]}$. Bojarskih and coworkers ${ }^{[7]}$ have compared the transcriptional profiles of young and aged human fibroblasts of three cell lines by means of the replicative aging model. The authors concluded that fibroblast aging has been accompanied with the manifested elevation of gene expression, coding secreted proinflammatory cytokines IL-6 (in 3.7 times; $p=0.05$ ), IL-8 (in 2.5 times; $p=0.04$ ) and insufficient rise of gene expression IL-1 $\beta$ (in 1.3 times; $p=0.04$ ).

Among proteins secreted by the aging cell, there are cytokines stimulating inflammatory response, some growth factors as well as secreted proteases and non-soluble components of the extracellular matrix. Therefore, aged cells exhibit capacity to alter their microenvironment and to regulate the characteristics of the adjusting cells by paracrine mechanisms ${ }^{[7]}$. All this demonstrates that skin immunity defects are progressing with increasing age.

\section{Antigen-presenting skin cells and aging}

The basic components of the cutaneous innate immunity are Langerhans cells (LC), dendritic cells (DC), and resident macrophages (RM). These antigen-presenting cells produce inflammatory mediators in response to toll-like receptors (TLRs)-signals, antigen-presence and provide T-cell co-stimulation both in skin and in drain lymph nodes. This section summarizes the results of several investigations, underlining the unique role of the antigenpresenting skin cells.

Skin DC count and phenotype are comparable in the young and elderly persons but migration, phagocytosis, and capability to stimulate T-cells may decrease ${ }^{[10,11]}$. Even if migration capability of aged DC being corrected, they are less effective in the antineoplastic immunity providing, correlating with the additional functional defect, associated with the selective dendritic cell-specific intercellular adhesion molecule-3-grabbing non-integrin (DC-SIGN) expression decreasing ${ }^{[12]}$. DC comparison in the elderly persons revealed the migration disturbances to MIP-1 $\beta$, notwithstanding the equivalent CCR7 expression ${ }^{[12]}$.

Plasmocytic dendritic cells (PDC) are the unique subpopulation of $\mathrm{DC}$, though their count in the normal skin being a few. Nevertheless, they play an important role in the viral infections (for example, herpes zoster virus) and inflammatory skin diseases (psoriasis, systemic lupus erythematosus and lichen planus ${ }^{[13,14]}$. PDC are also observed in skin tumors (melanoma, basal-cell cancer and squamous cell carcinoma $)^{[13,14]}$. Skin lesions induce the immediate PDC activation and transient IFN type 1 secretion, enabling wound healing ${ }^{[1,6]}$. In contrast to classical DC, cytokine secretion of PDC undoubtedly appear to deplete with aging ${ }^{[6,13]}$. Jing et al. ${ }^{[12]}$ reported the number of circulating PDC and IFNa production to decrease in the elderly persons. It is an obvious example why persons of advance age have frequent herpes zoster virus activation, displaying PDC function disturbances in the skin: their migration, activation and cytokine secretion.

Multiple functions of the macrophages disturb with aging, including TLR decreasing (or reduced cytokine response to TLR-stimulation), phagocytes functional ability as well as chemokine and cytokine secretion decreasing ${ }^{[13]}$. HRT-model demonstrates reduced macrophage ability in the antigen-activated elderly human skin to cytokine secretion, such as $\mathrm{TNF} \alpha$, accompanying the response to the antigen $^{[15]}$. TNF $\alpha$ strengthens the collagenolytic activity of matrix metalloproteinase (MMP)-1, presumably by MMP-3 activating, producing collagen type 1 gradual loss in human skin[16,17-19]. Reactive oxygen species (ROS), resulting because of the cell oxidative metabolism, are of an extreme importance in the aging process. ROS induce transcription factor c-Jun by means of mitogen-activated protein kinase (MAPK), affecting the elevated MMP-1, MMP-3 and MMP-9 expression ${ }^{[16]}$. Montecino-Rodriguez et al. ${ }^{[20]}$ do not exclude transforming growth factor (TGF) $\beta$ role in the aging mechanisms of the immune system.

Langerhans cells (LC) are the myeloid DC derived, populated permanently epidermally, closely interconnected with the keratinocytes. Until now, LC were considered the main antigen-presented skin cells responsible for the development of the immune response to the invaded pathogen $^{[7]}$. The traditional concept considers LC to invade and proceed the antigen, then to migrate to the lymph node, presenting antigen to $\mathrm{T}$-cells ${ }^{[5,7]}$. Per the latest data, LC play the key role in the inducing IL-22 secretion by 
the T-cells (Th22) which is an important element in the skin immune response. Other investigators suppose LC to play an important role in the suppressing of the immune response ${ }^{[6,7]}$. Thus, LC take part in UV-induced suppression, implementing via regulatory T-cells (T-regs) ${ }^{[6,7]}$. LC capacity to migrate into the drain nodes decreases in the elderly ${ }^{[9]}$. Summarizing these data, it might be supposed that a wide range of disturbances can appear in the leucocyte skin population while aging, although it is not clear, how it contributes to a greater dependency on the skin infections or malignant tumors ${ }^{[21]}$.

One of the defense mechanisms of the skin is the development of antimicrobial peptides-defensins and katelicidin that represent key molecular factors of immunity with a strong antimicrobial properties ${ }^{[22]}$. Yamshikova et al. ${ }^{[23]}$ have shown that antimicrobial peptides inhibit bacterial-induced production of cytokines and stimulate angiogenesis and wound healing. Defensins are divided into two groups: a-defensins and -defensins - which are chemotaxic for monocytes, $\mathrm{T}$ cells and immature $\mathrm{DC}^{[24,25]}$. Also defined q-defensins - a macrocyclic peptides expressed by leukocytes and bone marrow of primates, but not yet finalized, neither for the human, nor to other higher classificated primates ${ }^{[26]}$. There are four different types of a-defensin (human neutrophile peptides 1-4-HNP$1-4)^{[27]} . \beta$-defensins (human b-defensins (human -defensins 1-3-HBD-1-3) produced mainly by epithelial cells of the mucous membranes of the gastrointestinal, urogenital and respiratory tract ${ }^{[24,26]}$. HBD-1 is synthesized by epithelium, which is in constant contact with the medium or the microbial flora, as well as white blood cells, and it is all regulated by lipopolysaccharides and peptidoglycans. HBD2, as well as HBD-1 can be found in the skin, pancreas, leukocytes, and bone marrow. NBD-3 was detected in the heart, liver and placenta, and NBD4 - in the testes, epididymis, lung tissue tumors and gastric epithelial cells ${ }^{[27]}$.

In human skin, during wound healing, antimicrobic peptides are synthesized, in particular HBD-3 is expressed by LL-37-amino acid sequence and participates in transactivation of the epidermal growth factor receptor. Furthermore, defensins in keratinocytes promote development FNO $\alpha$, IFN $\gamma$, IL-1, IL-13 and IL-22. Katelicidin and HBD-1-4 are also present in the skin at low concentrations, in healthy humans, but injury or infection dramatically increases their synthesis ${ }^{[27]}$. Gibson et al. ${ }^{[28]}$ found a strong bactericidal effect of $\beta$-defensins in the skin in the treatment of burn wound colonizated by Staphylococcus aureus. Clausen et al. ${ }^{[29]}$ found changes in the level of $\beta$-defensins in the skin in atopic dermatitis, and the researchers found correlation between level of $\beta$-defensins and severity of atopic dermatitis. Patients with psoriasis show significantly reduced defensins level in the skin layer, which explains the high susceptibility to infectious diseases of the skin. Wittersheim et al. ${ }^{[30]}$ reported that the level of antimicrobial peptides in human skin depends on the age, with $\beta$-defensins twice higher in the elderly people.

Ultrastructure of the basal cells witnesses their active part in keratin synthesis as well as in preparation to other specific proteins synthesis. Basal layer is populated by stem cells of the G0-period. During mitosis, part of the cells transforms into transitional cells, the other part of the cell persists in the G0-period. Phenotype $\alpha 6$ 10G7 cells are shown to represent epidermal stem cells, composing the $8 \%$ of basal keratinocytes. Currently, the receptors to the vitamin D are detected on the stem cells. Nonetheless, all known nowadays markers fail to differentiate precisely the stem cells from the transitional ones. Keratinocytes synthesize membrane bound IL- $1 \alpha$, facilitating their own participation in the antigen presentation. Besides, keratinocytes synthesize IL-1 $\beta$, IL-3, IL-8, IL-15 and IL$19^{[31]}$. It is worth noting, that keratinocyte synthesized IL-1 enhances prostaglandin synthesis by the fibroblasts of the papillary layer. Prostaglandin, in its part, stimulates keratinocyte proliferation and differentiation. Keratinocyte recognition of pathogens by means of TLR 2 and TLR 4 results in proinflammatory cytokines production, among which precedence must be given to IL-8, responsible for the neutrophils, basophils, and leucocytes bringing to the epidermis.

All changes occurring with age, are characterized by the violation of the epithelial-stromal relations that underlie the formation of wrinkles. Type IV collagen is found in all basement membranes and plays an important role in adhesion, migration, differentiation and growth of cells. When photodamaging the skin occurs a reduction of thickness and level of border between derma and epidermis and particularly type IV collagen at the base of wrinkles. Byrne et al..$^{[32]}$ investigated the ability of ternary complex peptide (TCP) IV to stimulate collagen production in fibroblasts of the skin and its effects on the skin photoaging. Their results showed that stimulation of individual peptides of TCP does not lead to destruction of collagen IV. The combination of individual peptides is necessary to synergistically stimulate the production of collagen IV. The researchers suggest that the TCP can play a role in strengthening the border between derma and epidermis through its ability to stimulate collagen production.

Thus, it is possible that the decrease of immunity of the skin during aging may be related to impairment of innate immunity cells such as professional antigen-presenting cells, epithelial cells and fibroblasts.

\section{T-cells of the skin in the process of aging}

Normally, skin of a healthy person residents plenty of CD4+ and CD8+ T-cells. It has been estimated that approximately 20 billion of resident T-cells present in the skin of a healthy person, and about twice more are in the bloodstream $^{[7]}$. Intraepidermal lymphocytes present in the basal and suprabasal layers. They are thymus-dependent lymphocytes, subdividing into T-helpers (Th), T-killers and T-reg. T-helpers, in turn, subdivide into progenitor cells Th (Th0), effector lymphocytes, and memory lymphocytes. Th0 (expressing CD4) influenced by IL-2 and IL-12 differentiate into Th of the first type, not only secreting IL, IL-3, IFN $\gamma$ and TNF, but also stimulating T-killers maturation and production of $\operatorname{IgM}, \operatorname{IgG}$ and $\operatorname{IgA}$ by B-lymphocytes. Th of the second type produce IL-3, IL- 
4, IL-6 and stimulate different immunoglobulins synthesis by plasma cells. T-reg, suppressing the immune response, express CD8, CD45PA ${ }^{[31,33,34]}$. T-killers cause disturbance of allogenic cell permeability, resulting in their osmotic shock and subsequent necrocytosis ${ }^{[31]}$. Elucidating the T-helpers' new functions (for example, Th17, Th22 and T-reg cells) leads to the reframing of $\mathrm{T} 1 / \mathrm{T} 2$ paradigm, having been used for a long time for pathogenesis definition as well as cause of the infectious inflammatory and even tumor skin disease $^{[34]}$. Hereby, all abovementioned specificities of epidermis structural organization advocate in favor of its active part in the skin protective function.

\section{Toll-like receptors and aging}

Endothelial activation and skin homeostasis transformation at the point of the antigen exposure, promoting leucocytes access from the bloodstream, are thought to be due to the secretion of proinflammatory cytokines by innate immunity cells, triggering the "alarm signals" $[1,2]$. TLRs are one of the most common convertors of the "alarm signals" "[6,34], being the result of antigen exposure to the traumatized skin. TLRs are expressed by the different cells of innate immunity, including monocytes, macrophages, DC, and LC as well as keratinocytes. TLR-expression or TLR-induced inflammatory mediators' production by innate immunity cells are supposed to decline with age ${ }^{[35]}$. Moreover, the recent studies have demonstrated production decline of inflammatory cytokines, such as TFN $\alpha$, IL-6 and IL-12, from the circulating DC in elderly persons stimulated by the different TLR-ligands ${ }^{[36]}$. Consequently, skin immunity declines with aging is likely to be associated with the insufficiency of the innate immunity cells due to TLRsignals lesion.

Majority of human T-cells expresses CCR8 and acts as immunological surveillance cells, detecting epidermal APC, and triggering the safety program of the immune system, involving monocytes, granulocytes, inflammatory T-cells and antibodies ${ }^{[6]}$. T-cells of immunological surveillance play a dual role in this scheme. Firstly, responding the antigen impact, they start the inflammatory cascade by secreting TNF $\alpha$ and IFN $\gamma$, resulting in other leucocytes engagement. Secondly, these cells migrate into drain lymph nodes where they can proliferate or stimulate activation of antigen-specific $\mathrm{T}$ and $\mathrm{B}$-cell respond. Age skin immunity disturbances are likely to be also associated with the alterations of the resident T-cells. Intermittent long-life antigen stimulation might impair T-cells in two ways $^{[37]}$. Firstly, they become functionally depleted and loss their dominant functions significant for the immune defens $^{[7]}$. Functional depletion is a way to limitation of the effector T-cells' respond, commonly correlating with the elevating of expression of the surface receptors' inhibitors. Although, it may be a defense mechanism against autoimmune processes, but it jeopardies effectiveness of antiinflammatory and antitumor immunity ${ }^{[36,38]}$. Secondly, repetitive $\mathrm{T}$-cell stimulation can cause loss of replicative capacity of some antigen-specific T-populations because of telomeres shortening and/or DNA damage (process known as a replicative aging $)^{[21,34]}$. It is interesting, that escalating telomeres shortening is observed during immune skin response due to the inhibiting by IFN of the first type telomerase enzyme ${ }^{[21]}$.

Nowadays, it is doubtful whether resident or activated during immune response to antigen skin T-cells could deplete or age in the elderly persons, insight into this phenomenon is very essential. At present, elevation of the memory T-cells count is a well-known aging $\operatorname{sign}^{[6]}$. These cells generated after the first contact with the antigen are sustainable for a long time after the initial task, providing a source of effectors responding quickly to the antigen re-exposure. Over the time, exposure to the range of pathogens results in a diversity of the immune repertoire including the increased pool of the defensive memory cells. However, chronic stimulation with the viral infections, for example cytomegaloviruses, may deplete naïve cell pool and cause proliferation of the oligoclonal memory cells. This phenomenon is an important factor contributing to the CD8+ memory cells accumulating in the elderly persons ${ }^{[8]}$, but also $\mathrm{CD} 8+\mathrm{T}$-cells antigen independent proliferation may be evidenced ${ }^{[21,31]}$.

\section{Regulatory T-cells (T-reg) are accumu- lated in the skin with aging}

T-reg play a key role in a force of the immune response development. $5 \%-10 \%$ of the resident T-cells in the human skin in norm expresses Foxp3 and demonstrates other characteristics of the regulatory $\mathrm{T}-$ cells $^{[15]}$. These regulatory cells also proliferate during the response of delayed-type hypersensitivity (DHS) type. The investigations showed that T-reg circulate between the skin and lymph nodes and vice versa both at rest and in the immune response $\mathrm{e}^{[16]}$. These T-reg directly inhibit both T-cells and antigen-presenting cells, such as DC and macrophages. With the T-reg depletion, neutrophil infiltration rises significantly as the secondary response to the concentration rise of neutrophil chemoattractants (CXCL1 and CXCL2) $)^{[14]}$.

Elderly human and mice demonstrate the elevating of the ratio T-reg in the skin in norm ${ }^{[34]}$. T-reg can prevent effective primary proliferation/functioning of the resident antigen-specific T-cells or inhibit activation of the innate immunity respond, resulting in immunity decline. Negative effect of T-reg accumulation in the effective immune response is clearly described in the oncological diseases. T-reg count rising is reported to be noticed in primary melanoma, in metastatic melanoma, and in basal cellular carcinoma $^{[39]}$. Moreover, in squama-cellular skin carcinoma $50 \%$ of the T-cells presents Foxp3+[34]. Imiquimod topical treatment has shown to be effective in such patients, depleting T-reg percentage and decreasing their suppressive function ${ }^{[39]}$.

Causes and mechanisms of the T-reg accumulation in the skin and the other tissues in the elderly human and mice are not thoroughly obvious ${ }^{[15]}$. T-reg are known to be induced in the skin by the UV-rays and then such T-reg influence DC via IL-10, activating more T-reg through this "tolerant" $\mathrm{DC}^{[40]}$. Moreover, circulating T-reg may be directed preferentially into the skin, as their majority expresses the cutaneous lymphocyte-associated antigen 
(CLA). Summarizing all these data, it could be concluded that T-reg accumulation in the skin with aging may contribute into the insufficiency of the immune respond by the inhibiting of both T-cells, and the cells of the innate immune system.

\section{Antigen-specific response declining of the human skin in the process of aging is the reason of immune surveillance reduction}

The studies have shown that the elderly people have a reduced capability to maintain DHS - responds after antigen exposure ${ }^{[35]}$. This is manifested by the reduction of the erythema intensity and induration at the point of the antigen exposure as well as T-cells count depletion in the infiltrate proved by the immune-histologic methods. Since activation and skin strengthening immunity have been known to be an integrated step-by-step process, the experimental models in vivo proved to be more informative. Relatively useful is the experimental model of the DHS with the intradermal antigen exposure ${ }^{[35,40]}$. The extend of the DHS respond is determined by the diameter of the skin area infiltrate and erythema proliferation at the antigen injection site in 48 hours of its injection in human and edema severity of the auricles or feet in 24 hours in mice ${ }^{[40]}$. There are some differentiations in the kinetics and the nature of the disease in human and in mice, probably because of the different sites of the antigen injection but cell infiltrates are similar in both species ${ }^{[40]}$.

From the histological point of view, antigen exposure and skin integument injury induce nonspecific warning signals to the attraction and activation of the innate immunity cells, and on the earliest stages (4-6 hours) most of such cells are neutrophils ${ }^{[17,20]}$. Cell infiltration depends on the proinflammatory cytokines production, such as IFN $\gamma$ and TNF $\alpha$, stimulating adhesion molecule expression on the endothelium and increasing vascular permeability on the local level ${ }^{[1,2]}$. E-selectin is expressed on the capillary endothelium not later than 1-2 hours after antigen injection, and within 12 hours adhesion molecules inter-cellular adhesion molecule 1 (ICAM-1) and vascular cell adhesion molecule 1 (VCAM-1) are activated too. These molecules interact with lymphocyte function-associated antigen 1 (LFA-1) and very late antigen-4 (VLA-4) on the monocytes and lymphocytes, helping to ensure the concentration of these cells in the skin ${ }^{[15]}$. Simultaneously with the endothelium activation and transformation at the site of the antigen exposure, antigen-presenting cells transport antigen from the skin to the lymph node, presenting it to the activated T-cells migrating after that via blood vessels to the inflammatory lesion ${ }^{[2]}$. T-cells infiltration in DHS is a biphasic process, including early proliferation by these cells, emerging around dermic blood vessels approximately within 12 hours after antigen exposure ${ }^{[2]}$ and the subsequent accumulation peak of the antigen-specific T-cells which might be associated with these cell proliferation in the $\operatorname{skin}^{[1,2]}$. Maximum macrophages count is revealed within 24 hours, but in 48 hours the prevailing cells in the infiltrate are T-cells ${ }^{[2,39]}$.

The current scientific studies of the skin HSV-1 infection have proved that HSV-specific cells migrated to the site of antigen injection, staying resident in the skin till the antigen elimination $^{[1,6]}$. These long-living resident cells promote rapid response in the skin to the subsequent exposure of the same pathogen, presented by the tissue dendritic cells, and drive processes of the inflammatory cascade ${ }^{[2]}$. The immune response in the DHS type in the elderly human and mice has shown to have disturbances, these processes can reflect insufficient development of the immune memory to the antigen with aging.

The published data prove that DHS reaction to the bacteria, fungi, and viral antigens decreases with aging, despite the same capability of the T-cells to respond the same antigens in vitro ${ }^{[15]}$. It is noteworthy to suppose that the skin reactivity decrease is a local, not a systemic immunity defect, and it emphasizes the opportunity to highlight the disturbances of migration of the specific T-cells to the skin after the antigen exposure.

It has been unproved that decrease of T-cells capability to migrate after DHS is associated with the insufficiency of the expression of the chemokine receptors or integrin by the circulating $\mathrm{T}$-cells ${ }^{[15]}$. Moreover, $\mathrm{T}$-cells in the elderly persons also retained their migrative properties while passing through a monolayer of endothelial cells in vitro $^{[15]}$. It is conceivable that instead of the DHS-response insufficiency, there is a decrease of the endothelium activation. Endothelium activation is driven by E-selectin, VCAM and ICAM adhesion molecules are the key chains in the T-cells transmigration to the cell. TNF $\alpha$ and IFN $\gamma$ are the basic inductors of the endothelium activation and DHS-response in young persons, these cytokines are predominantly secreted by the macrophages ${ }^{[21]}$. In the elderly persons, their secretion was significantly decreased at the site of antigen injection after its exposure, despite the macrophages count stayed at the normal level ${ }^{[21]}$. Macrophages isolated from the skin, remained fully capable to secrete these cytokines and stimulated TLR-ligands in vitro, supposing their inhibition in vivo. Relevance of TNF $\alpha$ for the effective skin immune response has been proved by the isolated cases of the observation of the sensitivity increase in rheumatoid patients to the cutaneous infections and tumor masses while being treated by the anti-TNFmedications $^{[13]}$

An explanation to the proinflammatory cytokines' secretion decrease in response to antigen exposure in the elderly persons might be T-reg ratio elevation, inhibiting macrophage activation, and cytokine secretion. T-reg have demonstrated to inhibit $\mathrm{TNF} \alpha$ secretion, transmitting macrophages and creating the anti-inflammatory profile ${ }^{[10]}$.

\section{Conclusion}

Immunological skin aging is a multifactorial process and it is evident that different cells become defect with aging. DHS reaction and memory $\mathrm{T}$-cells respond are impaired in the elderly persons. Defects might not be inhered in the T-cells, but are rather in their environment, in the site of antigen exposure, thus resulting in the insufficient 
endothelium activation and failure of the adequate migration of the circulating T-cells to the place of destination. Skin immune respond reducing to the antigen may be related both to the adaptive and to the innate immunity, T-reg count elevating, revealed in a wider range of the elderly persons. Thus, all the mechanisms of immune system weakening, including the older age, are not completely known. Ample evidence poses the number of questions as to whether the T-reg and others cells activity correction in the skin could increase the immunological surveillance in the elderly persons, improve its quality and reduce risk of malignant tumor or cutaneous infection development.

\section{References}

1. Jarilin AA. КОЖА И ИММУННАЯ СИСТЕМА (Russian) [The skin and the immune system]. Kosmetika i medicina 2001; 2: 5-13.

2. Karaulov AV, Bykov SA, Bykov AS. ИММУНОЛОГИЯ, МИКРОБИОЛОГИЯ И ИММУНОПАТОЛОГИЯ КОЖИ (Russian) [Immunology, microbiology and skin immunopathology]. Moskva: Izdatel'stvo BINOM; 2012.

3. Laube S. Skin infections and ageing. Ageing Res Rev 2004; 3(1): 69-89. doi: 10.1016/j.arr.2003.08.003.

4. Bazarnyj VV. Иммунная система кожи (Russian) [The immune system of the skin]. Mezoterapija 2011; 2(14): 28-36.

5. Parahonskij АР. РОЛЬ ИММУННЫХ МЕХАНИЗМОВ В СТАРЕНИИ ОРГАНИЗМА (Russian) [The role of immune mechanisms in the aging body]. Mezhdunarodnyj zhurnal prikladnyh i fundamental'nyh issledovanij 2011; 6: 74.

6. Sepiashvili RI. Физиология иммунной системы (Russian) [Physiology of the immune system]. Moskva: Medicina Zdorov'e 2015.

7. Bojarskih UA, Surovceva MN, Smetanina MA, Kel' A. Je, Serov OL, et al. Увеличение экспрессии ичитокинов, сопровождающее старение фибробластов человека in vitro (Russian) [Increased expression of cytokines, accompanied by the aging of human fibroblasts in vitro]. Vestnik Novosibirskogo gosudarstvennogo universiteta 2012; 10(3): 11-18.

8. Hardeland R. Melatonin and the theories of aging: A critical appraisal of melatonin's role in antiaging mechanisms. J Pineal Res 2013; 55(4): 325-356. doi: 10.1111/jpi.12090.

9. Gomez CR, Plackett TP, Kovacs EJ. Aging and estrogen: Modulation of inflammatory responses after injury. Exp Gerontol 2007; 42(5): 451-456. doi: 10.1016/j. exger.2006.11.013.

10. Mahbub S, Brubaker AL, Kovacs EJ. Aging of the innate immune system: An update. Curr Immunol Rev 2011; 7(1): 104-115.doi: 10.2174/157339511794474181.

11. Kovacs EJ, Palmer JL, Fortin CF, Fulop T Jr, Goldstein DR, et al. Aging and innate immunity in the mouse: Impact of intrinsic and extrinsic factors. Trends Immunol 2009; 30(7): 319-324. doi: 10.1016/j.it.2009.03.012.

12. Jing Y, Shaheen E, Drake RR, Chen N, Gravenstein S, et al. Aging is associated with a numerical and functional decline in plasmacytoid dendritic cells, whereas myeloid dendritic cells are relatively unaltered in human peripheral blood. Hum Immunol 2009; 70(10): 777-784. doi: 10.1016/ j.humimm.2009.07.005.

13. Shaw AC, Joshi S, Greenwood H, Panda A. Lord J.M. Aging of the innate immune system. Curr Opin Immunol 2010; 22(4): 507-513. doi: 10.1016/j.coi.2010.05.003.

14. Markelova EV, Prosekova EV, Skljar LF, Chepurnova NS,
Nagornaja AV. Персистирующие вирусные инфекиии: этиология и иммунопатогенез (Russian) [Persistent viral infections]. Vladivostok: Medicina-DV 2016.

15. Agius E, Lacy KE, Vukmanovic-Stejic M, Jagger AL, Papageorgiou AP, et al. Decreased TNF- $\alpha$ synthesis by macrophages restricts cutaneous immunosurveillance by memory CD4+ T cells during aging. J Exp Med 2009; 206(9): 1929-1940. doi: 10.1084/jem.20090896.

16. Papakonstantinou E, Roth M, Karakiulakis G. Hyaluronic acid: A key molecule in skin aging. Dermatoendocrinol 2012; 1(4):253-258. doi: 10.4161/derm.21923.

17. Zhaoping Q, Voorhees JJ, Fisher GJ, Quan T. Age-associated reduction of cellular spreading/mechanical force up-regulates matrix metalloproteinase-1 expression and collagen fibril fragmentation via c-Jun/AP-1 in human dermal fibroblasts. Aging Cell 2014; 13(6): 1028-1037. doi: 10.1111/acel.12265.

18. Ågren MS, Schnabel R, Christensen LH, Mirastschijskif U. Tumor necrosis factor- $\alpha$-accelerated degradation of type I collagen in human skin is associated with elevated matrix metalloproteinase (MMP)-1 and MMP-3 ex vivo. Eur J Cell Biol 2015; 94(1): 12-21. doi: 10.1016/j.ejcb.2014.10.001.

19. Xia W, Hammerberg C, Li Y, He T, Quan T, et al. Expression of catalytically active matrix metalloproteinase-1 in dermal fibroblasts induces collagen fragmentation and functional alterations that resemble aged human skin. Aging Cell 2013; 12(4): 661-671. doi: 10.1111/acel.12089.

20. Montecino-Rodriguez E, Berent-Maoz B, Dorshkind K. Causes, consequences, and reversal of immune system aging. J Clin Invest 2013; 123(3): 958-965. doi: 10.1172/JCI64096.

21. Bennett MF, Robinson MK, Baron ED, Cooper KD. Skin immune systems and inflammation: Protector of the skin or promoter of aging? J Investig Dermatol Symp Proc 2008; 13(1): 15-19. doi: 10.1038/jidsymp.2008.3.

22. Zurochka AV, S uhovej J u G, Z u roch -

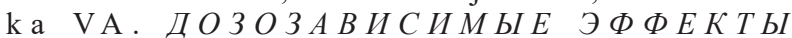
А Н ТИБАК Т Е РИ АЛ ВНОГО Д ЕЙ С Т В ИЯ СИНТЕТИЧЕСКОГО ПЕПТИДА АКТИВНОГО ЦЕНТРА $G M-C S F$ (Russian) [Disability effects of antibacterial action of synthetic peptide of the active site of GM-CSF]. Infekcija i immunitet 2012; 2(3): 657-660.

23. Jamshhikova EV, Orlov DS, Pazina ТЈu. ВЛИЯНИЕ АНТИМИКРОБНОГО ПЕПТИДА БАКТЕНЕЦИНА 5 И ЕГО УКОРОЧЕННЫХ ФРАГМЕНТОВ НА ПРОЛИФЕРАЦИЮ ФИБРОБЛАСТОВ КОЖИ ЧЕЛОВЕКА И НА ПРОЦЕСС ЗАЖИВЛЕНИЯ РАН У ЭКСПЕРИМЕНТАЛЬНЫХ ЖИВОТНЫХ (Russian) [Effect of antimicrobial peptide bactenecin 5 and its shorter fragments on proliferation of human skin fibroblasts and the wound healing process in experimental animals]. Ovremennye problemy nauki i obrazovanija 2012; 3. Avalible from: http://www.science-education.ru/103-6127.

24. Gankovskaja LV, Bogomil'skij MR, Gankovskaja OA. РОЛЬ ДЕФЕНСИНОВ КАК ФАКТОРОВ ВРОЖДЕННОГО ИММУНИТЕТА В ЗАЩИТЕ ОРГАНИЗМА ДЕТЕЙ С ТЯЖЕЛЫМИ ФОРМАМИ ПАРАТОНЗИЛЛИТОВ (Russian) [The role of defensins as factors of innate immunity in protecting the body children with severe paratonsillitis]. Jepidemiologija i Vakcinoprofilaktika 2011; 5: 30-33.

25. Aleshina GM, Jankelevich IA, Kokrjakov VN. РАЗРАБОТКА ИММУНОФЕРМЕНТНОЙ ТЕСТ-СИСТЕМЫ ДЛЯ КОЛИЧЕСТВЕННОГО ОПРЕДЕЛЕНИЯ ДЕФЕНСИНОВ ИЗ НЕЙТРОФИЛЬНЫХ ГРАНУЛОЦИТОВ КРЫС (Russian) [Development of enzyme immunoassay system for quantitative determination of defensins from neutrophils of rats]. Biologicheskie nauki 2013; 11: 1347-1351. 
26. Hemshekhar M, Anaparti V, Mookherjee N. Functions of cationic host defense peptides in immunity. Pharmaceuticals 2016; 9(3): 40. doi: 10.3390/ph9030040.

27. Auvynet C, Rosenstein Y. Multifunctional host defense peptides: Antimicrobial peptides, the small yet big players in innate and adaptive immunity. FEBS Journal 2009; 276(22): 6497-6508. doi: 10.1111/j.1742-4658.2009.07360.x.

28. Gibson AL, Thomas-Virnig CL, Centanni JM, Schlosser SJ, Johnston CE, et al. Non-viral human beta defensin-3 expression in a bioengineered human skin tissue: A therapeutic alternative for infected wounds. Repair Regen 2012; 20(3): 414-424. doi: 10.1111/j.1524-475X.2012.00786.x.

29. Clausen ML, Jungersted JM, Andersen PS, Slotved HC, Krogfelt KA, et al. Human $\beta$-defensin-2 as a marker for disease severity and skin barrier properties in atopic dermatitis. Brit J Dermatol 2013; 169(3): 587-593. doi: 10.1111/bjd.12419.

30. Wittersheim M, Cordes J, Meyer-Hoffert U, Harder J, Hedderich J. Differential expression and in vivo secretion of the antimicrobial peptides psoriasin (S100A7), RNase 7, human $\beta$-defensin-2 and -3 in healthy human skin. Exp Dermatol 2013; 22(5): 358-379. doi: 10.1111/exd.12133.

31. Kuznecov SL, Gorjachkina VL, Comartova DA, Zaborova VA, Lucevich OA. СОВРЕМЕННЫЕ ПРЕДСТАВЛЕНИЯ О СТРУКТУРЕ И ФУНКЦИЯХ ЭПИДЕРМИСА (Russian) [Modern ideas about the structure and functions of the epidermis]. Rossijskij zhurnal kozhnyh i venericheskih boleznej 2013; 2: 26-32.

32. Byrne A, Al-Bader T, Kerrigan D, Rawlings AD. Synergistic action of a triple peptide complex on an essential extracellular matrix protein exhibits significant anti-aging benefits. J Cosmet Dermatol 2010; 9(2): 108-116. doi: 10.1111/j.14732165.2010.00494.x.

33. Reva IV, Reva GV, Jamamoto T, Mozhilevskaja ES, Danilenko MV, et al. РЕГУЛЯЦИЯ ПРОЛИФЕРАТИВНОЙ АКТИВНОСТИ ЭПИТЕЛИЕВ (Russian) [Regulation of the proliferative activity of the epithelium]. Fundamental'nye issledovanija 2014; 4: 343-346.

34. Bangert C, Brunner PM, Stingl G. Immune functions of the skin. Clin Dermatol 2011; 29(4): 360-376. doi: 0.1016/ j.clindermatol.2011.01.006.

35. Shaw AC, Panda A, Joshi SR, Qian F, Allore HG, et al. Dysregulation of human Toll-like receptor function in aging. Ageing Res Rev 2010; 10(3): 346-353. doi: 10.1016/ j.arr.2010.10.007.

36. Abdrashitova AT, Belolapenko IA, Buchin VN. РОЛЬ БЕЛКА Р5З И ИНТЕРЛЕЙКИНОВ $8,10,18$ В РАЗВИТИИ ПРЕЖДЕВРЕМЕННОГО СТАРЕНИЯ ЛИЦ, ЗАНЯТЫХ НА ПРОИЗВОДСТВЕ ПО ДОБЫЧЕ ГАЗА (Russian) [Role of P53 protein and interleukin- 8 , interleukin-10, interleukin-18 in the development of premature aging of persons engaged in the production of gas production]. Kubanskij nauchnyj medicinskij vestnik 2011; 3(126): 8-12.

37. Akbar AN, Henson SM. Are senescence and exhaustion intertwined or unrelated processes that compromise immunity? Nat Rev Immunol 2011; 11(4): 289-295. doi: 10.1038/ nri2959.

38. Schwarz A, Noordegraaf M, Maeda A, Torii K, Clausen $\mathrm{BE}$, et al. Langerhans cells are required for UVR-induced immunosuppression. J Invest Dermatol 2010; 130(5): 14191427. doi: $10.1038 /$ jid.2009.429.

39. Plehova NG, Somova LM. РОЛЬ МОНОЦИТОВ/ МАКРОФАГОВ В ПАТОГЕНЕЗЕ ВИРУСНЫХ ИНФЕКЦИЙ (Russian) [The role of monocytes/macrophages in the pathogenesis of viral infections]. Tihookeanskij medicinskij zhurnal 2010; 3(41): 5-9.

40. Schwarz A, Schwarz T. UVR-induced regulatory T cells switch antigen-presenting cells from a stimulatory to a regulatory phenotype. J Invest Dermatol 2010; 130(7): 1914-1921. doi: 10.1038/jid.2010.59. 